\title{
Contribution of Rhizosphere Processes to Acacia Seedlings Adaptation into Polluted Soils of a Municipal Landfill (Côte d'Ivoire)
}

\author{
BOLOU-BI B. Emile ${ }^{1 *}$, KRAIDY N'gattah B. Armel ${ }^{1}$, SERME Aboudoukarime ${ }^{1}$, ETTIEN D. \\ Jean Baptiste ${ }^{1}$, BALLAND-BOLOU-BI Clarisse ${ }^{2}$ \\ ${ }^{1}$ Département des Sciences du Sol, Unité de Formation et Recherche des Sciences de la Terre et des Ressources \\ Minières, Université Félix Houphouët-Boigny, 22 BP 582 Abidjan 22, Abidjan, Côte d'Ivoire. \\ ${ }^{2}$ Laboratoire Eau Environnement et Système Urbain UMR MA 102, Faculté des Sciences et Technologie, \\ Université Paris-Est Créteil, 61 Avenue du Général de Gaulle, 94010 Créteil Cedex, France \\ ${ }^{3}$ Nigerian Correctional Service, Headquarter, Abuja, Nigeria
}

*Corresponding Authors: BOLOU-BI B. Emile, Département des Sciences du Sol, Unité de Formation et Recherche des Sciences de la Terre et des Ressources Minières, Université Félix Houphouët-Boigny, 22 BP 582 Abidjan 22, Abidjan, Côte d'Ivoire.

\begin{abstract}
Inadequate urban waste management in Côte d'Ivoire is the heavy metal source in soils used to produce vegetables. This represents a potential risk of food contamination. In order to find an efficient technique for soils depollution before their use in agriculture, an experimental study had demonstrated the ability of species of Acacia (mangium, auriculiformis and crassicarpa) to extract heavy metals from landfill soils. This work was undertaken to determine rhizosphere processes controlling Acacia growth in polluted soil. An experiment was carried out in hydroponic culture and on thin layer of landfill polluted soil during 3 months. During this experiment, growth parameters, soil chemical properties, heavy metal contents in soil (total and various fractions) and in plants were measured at the end of experiment. Results show that plant growth is related to the development of strategies in root zone. Plants released protons in their rhizosphere and lowering the redox potential, especially under Acacia crassicarpa, which stored the most level of heavy metal in in biomass. The other species produce organic acids allowing plants to grow with high biomass in soil with high content of heavy metal. Acacia crassicarpa is therefore the species better suited for depollution of landfill soil.
\end{abstract}

Keywords : Acacia, Rhizosphere, Phytoremediation, Heavy metal, Landfill, Soil

\section{INTRODUCTION}

Many cities in Côte d'Ivoire have a rapid expansion inducing large production of household waste (Soro et al. 2010). In the District of Abidjan, the average household waste production per capita increased by $8.3 \%$ for a population rise of $15.4 \%$ in the period of $1998-2005$. Due to a lack of adequate management infrastructures, these urban wastes are collected and stored in open dumps. These dumps, formerly on the outskirts of cities, are now in the center of cities. Landfilling municipal waste was the most widely used waste disposal technique in Africa because it is easy to implement and relatively inexpensive. Nevertheless, landfilling induces environmental degradation through the production of leachates that carry a significant pollutant load (Khattabi 2002), inducing soil and groundwater degradation. Municipal waste dumped contains chemical elements like pharmaceuticals materials, used oils, batteries and organic household waste. The biogeochemical degradation of waste releases therefore trace metals in soils. Consequently, successive accumulation of municipal waste lead to an increase in trace metals and others pollutants contents in landfill. Because of their high concentrations, trace metal percolate with leaching solutions and contribute to polluting water resources, soil solutions and plants (Fonge et al. 2017; Edokpayi et al. 2017). Trace metal mainly encountered in tropical landfill soils are Arsenic (As), Cadmium (Cd), Chromium (Cr), Copper (Cu), Mercury (Hg), Nickel (Ni), Lead (Pb), Selenium (Se) and Zinc (Zn) (Kouamé et al. 2006).

Despite soil pollutions in trace metals, urban landfills play an economic key role in most of cities of Côte d'Ivoire, as they are used to produce fresh vegetables for urban population. Vegetables production on landfill soils may induce food contamination in pollutants via the transfer of trace metals from soil 
to vegetables (Guety et al. 2015; Vittori-Antisari et al. 2015; Nanven et al. 2015; Vongdala et al. 2018). Numerous studies have shown that regular consumption of vegetables grown on soil polluted into trace metals contribute to human contamination into trace metals (Ferry et al. 2015; Uddh-Soderberg et al. 2015). In order to secure vegetable production in urban landfills, it appears necessary to restore soil quality by using appropriate methods.

Several soil remediation techniques are known to date. Biological method, using plants, appears as the best adapted in urban context. Acacia is a tropical plant well adapted in soil with high levels of trace metals. This plant is increasingly used in soil remediation, particularly in Asia due to their rapid growth and large root biomass production (Ricardo et al. 2012; Mohd et al. 2013). Thus, Acacia mangium has been tested in metal-contaminated soils and displayed a high capacity for trace metal absorption (Majid et al. 2012). A. mangium accumulates and stores cadmium $(\mathrm{Cd})$ and lead $(\mathrm{Pb})$ in the stem, while chromium $(\mathrm{Cr})$, copper $(\mathrm{Cu})$ and arsenic $(\mathrm{As})$ are stored in the roots. Zinc $(\mathrm{Zn})$ is translocated and stored in the leaves (Henrique et al. 2013). However, biological mechanisms inducing the Acacia growth and implementation in metal-polluted soils are still unknown. The objective of this study is therefore to investigate the adaptation mechanisms of Acacia in metal-polluted landfill soils. We hypotheses that these adaptation mechanisms in polluted soils are related to rhizospheric processes inducing solubilization and transformation of metals into various forms that are less toxic to the plant.

\section{Materials AND Methods}

\subsection{Biological Material}

The plant material consists of three species of Acacia that are Acacia mangium, Acacia auriculiformis and Acacia crassicarpa. The seeds were provided by the National Center for Agronomic Research (CNRA) based in Abidjan (Côte d'Ivoire).

\subsection{Growth Substrates and Nutrient Solution}

Soil samples: Soil were sampled in municipal landfill located in Bonoua city (Figure 1). Soil is characterized as an anthropogenic soil in the WRB system. About 30 soil samples were randomly taken from 0 to $20 \mathrm{~cm}$ deep in the landfill. Then, a composite sample was made from these different samples for experiment.

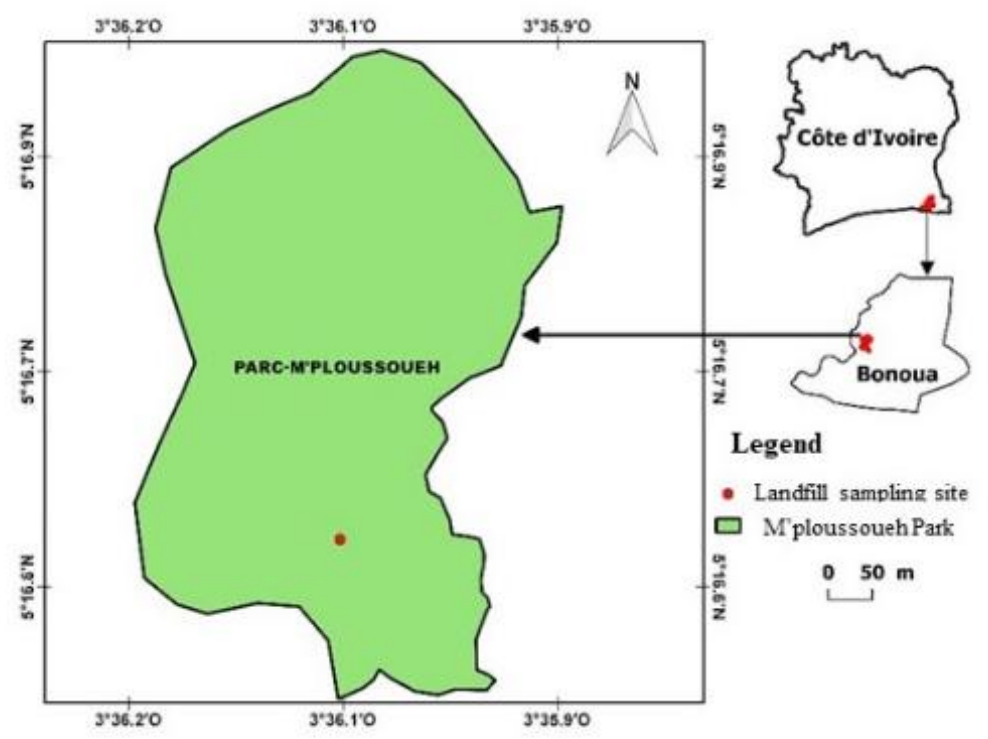

Figure 1: Site of Bonoua municipal landfill

Coconut fibber: It is fibber of the coconut mesocarp, which is composed mainly of coarse fibber but also a fine material known as coconut dust or coconut peat. It is used in agriculture as hydroponic growth substrate due to its a good water retention capacity and high capillary power as well as high structural stability.

Nutrient solution: The nutrient solution used for plant growth was prepared with 101 of distilled water and mineral salts. Its composition is given in Table 1. 
Table1. Chemical composition of nutrient solution used for plant growth

\begin{tabular}{|l|l|l|}
\hline Salts & Initial solution $(\mathbf{M})$ & Diluted solution $(\boldsymbol{\mu M})$ \\
\hline MgSO4 7H2O & 1.00 & 1.00 \\
\hline $\mathrm{KH} 2 \mathrm{PO} 4$ & 1.00 & 0.50 \\
\hline $\mathrm{CH} 4 \mathrm{~N}_{2} \mathrm{O}$ & 1.00 & 2.00 \\
\hline $\mathrm{Ca}\left(\mathrm{H}_{2} \mathrm{PO} 4\right) 2$ & 1.00 & 2.00 \\
\hline $\mathrm{Na} 2 \mathrm{~B} 4 \mathrm{O} 7$ & 0.10 & 10.00 \\
\hline $\mathrm{Na} 2 \mathrm{MoO} 42 \mathrm{H}_{2} \mathrm{O}$ & 0.10 & 5.00 \\
\hline FeNaEDTA & 0.01 & 0.50 \\
\hline
\end{tabular}

\subsection{Experimental Growth}

Plant seeds were disinfected with sulfuric acid $\left(\mathrm{H}_{2} \mathrm{SO}_{4}\right)$ concentrated at 95-97\% for 1 hour, and then thoroughly rinsed with distilled water. The seeds were then soaked in distilled water for 24 hours, and placed on solidified agar medium in an oven at $30^{\circ} \mathrm{C}$ for 72 hours for germination. After germination, growth experiment was carried out firstly hydroponic culture. Seedlings were transplanted on coconut fibber previously rinsed with distilled water. Plants were watered every morning with $40 \mathrm{ml}$ of the nutrient solution. After 8 weeks, the plants were transferred to a second experimental device with a fine layer of landfill soil to study the rhizosphere processes using the rhizotron (Figure 2), for 6 weeks.

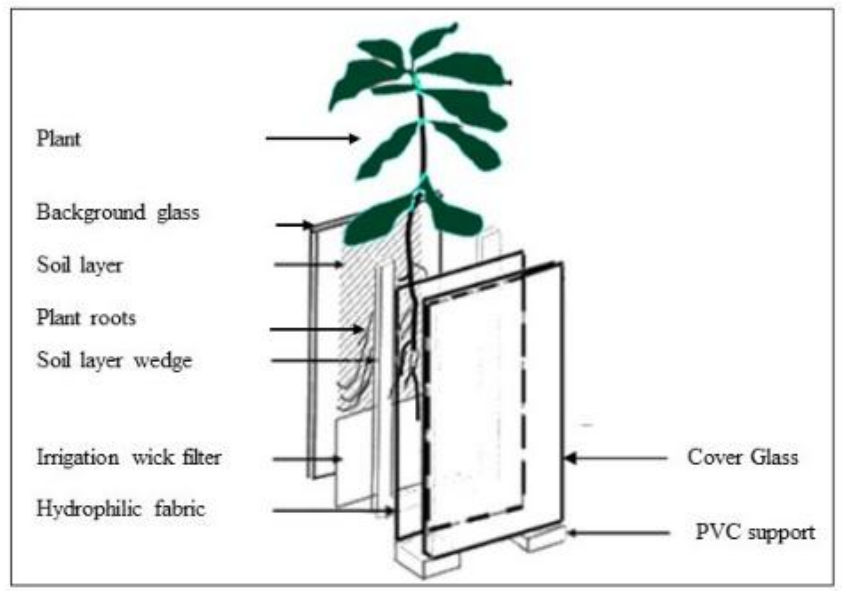

Figure 2: Schematic representation of the rhizotron experimental device.

The experimental growth was conducted in greenhouse with three repetitions per species and controls. During the experimental growth, plant heights were recorded every two weeks.

\subsection{Sampling and Treatment}

After growth in the rhizotron, plants were harvested and roots rinsed with distilled water. The shoots and roots were separated, and oven dried at $65^{\circ} \mathrm{C}$ for 72 hours. Shoots and roots were then weighed to determine dry biomass. Then, samples were crushed and sieved to $25 \mu \mathrm{m}$ to uniform the grain size.

Soil samples were dried in oven at $105^{\circ} \mathrm{C}$ for 24 hours. These samples were then separated in two fractions. The first fraction was used to extract successively exchangeable and acid-soluble metal fractions. For this, $2 \mathrm{~g}$ of soil were mixed with $10 \mathrm{ml}$ of $1 \mathrm{M}$ solution of $\mathrm{MgCl}_{2}, 6 \mathrm{H}_{2} \mathrm{O}$. The mixture was stirred for 1 hour at $20 \mathrm{rpm}$ and centrifuged at $3000 \mathrm{rpm}$. The supernatant were filtered at $0.45 \mu \mathrm{m}$ porosity with Whatman filter ${ }^{\circledR}$. Soil residues obtained were used to extract the acid-soluble fraction extracted with $20 \mathrm{ml}$ of an acid mixture $\left(0.05 \mathrm{M} \mathrm{HCl}\right.$ and $\left.0.0125 \mathrm{H}_{2} \mathrm{SO}_{4}\right)$ (Mulchi et al. 1992) in the same conditions than exchangeable fraction. Both extracted solutions were stored at $4^{\circ} \mathrm{C}$ until analyses. The second soil fraction crushed and sieved at $10 \mu \mathrm{m}$ to standardize the particle size for bulk analyses.

\subsection{Chemical Analyses of Samples}

\section{5. 1. $\mathrm{pH}$ and Redox Potential measurement}

The $\mathrm{pH}$ measurement was performed on soil samples using the $\mathrm{pH}$ meter $\left(\mathrm{VWR}^{\circledR}\right)$ in three replicates per sample in soil/solution ratio of $1 / 5(\mathrm{~g} / \mathrm{ml})$. 
The redox potential is used to describe a system's overall reducing or oxidizing capacity. About $10 \mathrm{~g}$ of soil were placed in plastic tube sets and gently compacted with intermittent additions of distilled deionized water to reach flooded conditions. Then, the mixture were stored at room temperature. After 24 hours equilibration period, redox potential (Eh) were measured in mixture using Bante ${ }^{\circledR}$ ORP probe.

\subsubsection{Proton efflux}

Proton efflux is the release of protons by plants in the growth medium. The amount of $\mathrm{H}^{+}$released by the roots is determined by the change in $\mathrm{pH}$ relative to control soil. In soils, the amount of $\mathrm{H}^{+}$released is given by the relation:

$\boldsymbol{Q} \boldsymbol{H}^{+}=(\boldsymbol{\beta} * \Delta \boldsymbol{p H} * \boldsymbol{M}) / \Delta \boldsymbol{t}$

where: $\mathbf{Q H}^{+}$is the amount of $\mathrm{H}^{+}\left(\mu \mathrm{mol} \mathrm{H^{+ }} \cdot \mathrm{g}^{-1}\right.$.day $\left.{ }^{-1}\right), \square$ is the buffer capacity of control soil $(\mu \mathrm{mol} \mathrm{OH}$ .soil $\left.\mathrm{pH}^{-1}\right), \Delta \mathbf{p H}$ is the $\mathrm{pH}$ change in $\mathrm{pH}$ of soil and control ( $\mathrm{pH}$ unit), $\mathbf{M}$ is the mass of soil ( $\mathrm{g}$ ) and $\Delta \mathbf{t}$ is the culture time (days).

\subsubsection{Low molecular mass organic acids (LMMOAs)}

Extraction of LMMOAs was realized by adding $10 \mathrm{ml}$ of MilliQ water to $1 \mathrm{~g}$ of air-dried soil. After 2 hour of shaking, the supernatant was filtered at $0.2 \mu \mathrm{m}$ (PTFE, VWR ${ }^{\circledR}$ ), freeze-dried (Christ Alpha 1-2; $-40^{\circ} \mathrm{C}$ ) during $24 \mathrm{~h}$ hours in order to concentrate extracted LMMOAs of soil solution. The LMMOAs were then suspended again by adding $1 \mathrm{ml}$ of MilliQ water. The quantification of LMMOAs performed using High Pressure Liquid Chromatography (HPLC). Samples were run on a C18 stationary phase (AQUASIL C18, $5 \mu \mathrm{m}, 250 \times 4.6 \mathrm{~mm}$ ) using a mobile phase of $1 \% \mathrm{ACN} / 99 \% 0.05 \mathrm{M} \mathrm{KH}_{2} \mathrm{PO}_{4}, \mathrm{pH}$ 2.8 at a flow rate of $1.25 \mathrm{ml} \mathrm{min}$. The column was operated at $20{ }^{\circ} \mathrm{C}$ for detection of oxalic, acetic, formic, glutaric, malic, malonic, succinic, maleic, fumaric and citric acid. The citric acids were detected at $210 \mathrm{~nm}$ by a photodiode array detector.

\subsubsection{Trace metal}

For plant samples, about $200 \mathrm{mg}$ of sample were added to a teflon digestion with $1 \mathrm{ml}$ of hydrogen peroxide $\left(30 \%\right.$, ARISTAR $\left.{ }^{\circledR}\right)$ and $3 \mathrm{ml}$ of nitric acid $\left(67 \%\right.$, NORMATOM $\left.{ }^{\circledR}\right)$ at room temperature for 24 hours. Then, the mixture were heated at $90{ }^{\circ} \mathrm{C}$ overnight. After cooling, obtained solutions were evaporated to dryness and residues redissolved in $1 \mathrm{ml}$ of hydrochloric acid (35\%, ARISTAR $\left.{ }^{\circledR}\right)$ and heated at $75{ }^{\circ} \mathrm{C}$ for 8 hours. Solutions are filtered using Whatman ${ }^{\circledR}$ filters into $50 \mathrm{ml}$ volumetric flasks.

For soil samples, $10 \mathrm{mg}$ of dried soil samples were introduced into a Teflon beaker. Then, $6 \mathrm{ml}$ of a solution of hydrochloric acid $\left(35 \%\right.$, ARISTAR $\left.^{\circledR}\right)$ and $2 \mathrm{ml}$ of nitric acid $\left(67 \%\right.$, NORMATOM $\left.{ }^{\circledR}\right)$ are added to the beaker and heated at $125^{\circ} \mathrm{C}$ overnight. Obtained solutions are evaporated to dryness and residues are taken up in $2 \mathrm{ml}$ of hydrochloric acid and heated at $95{ }^{\circ} \mathrm{C}$ overnight. Solutions were then filtered using Whatman ${ }^{\circledR}$ filters in $50 \mathrm{ml}$ volumetric flasks.

\subsection{Statistical Treatments}

For soil, solution and biological characteristics, each analysis was run in triplicate. Significant differences between each treatment were determined by analyzing variance (ANOVA 1 factor) and by the Tukey HSD test (significance threshold of $p<0.05$ with $n=3$ ) (XLSTAT version 20146.01 ).

\section{Results}

\section{1. Growth Parameters}

Figure 3 shows plant height evolution during experimental growth. During hydroponic growth, all species (A. auriculoformis, A mangium and A. crassicarpa) display the same behavior with regular growth from approximatively $7 \mathrm{~cm}$ at the $4^{\text {th }}$ week to approximatively $20 \mathrm{~cm}$ at the $8^{\text {th }}$ week. In rhizotron, plant heights were not significantly different until $10^{\text {th }}$ week reaching on average $\sim 23 \mathrm{~cm}$. From the $12^{\text {th }}$ week, difference were significant between plants. Indeed, A. auriculoforis had the greatest growth with a height of $\sim 27 \mathrm{~cm}$ at the $10^{\text {th }}$ week and reached a height of $45 \mathrm{~cm}$ at the end of experiment. The other two plants had a moderate growth with a height of $21 \mathrm{~cm}$ at the $10^{\text {th }}$ week to reach a height of $25 \mathrm{~cm}$ and $30 \mathrm{~cm}$ at the end of experiment for A. crassicarpa and A. mangium respectively. 


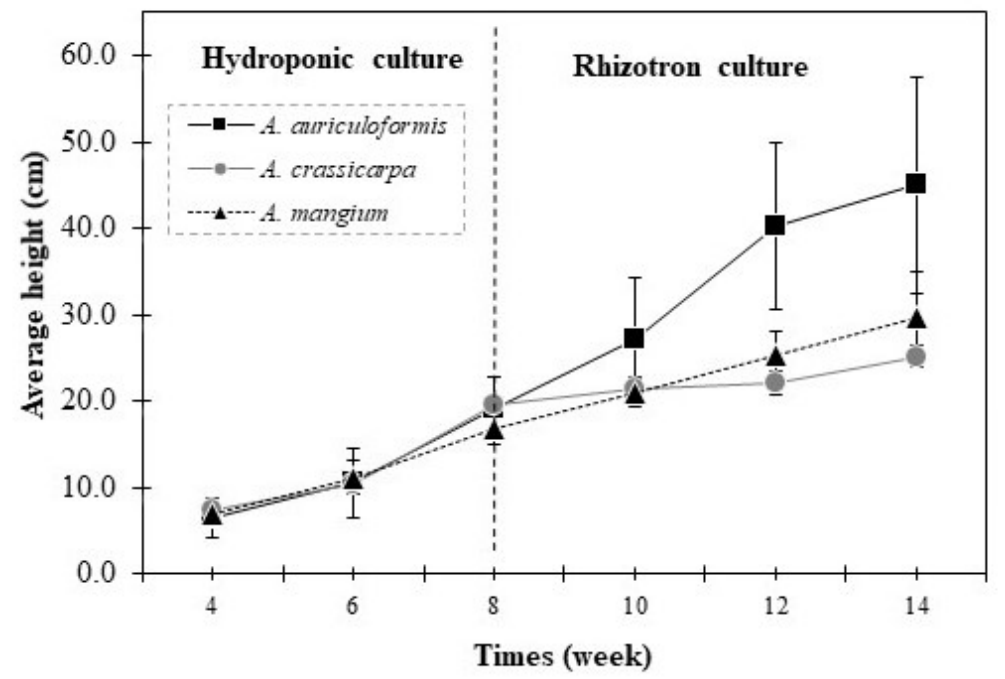

Figure 3 Plant height evolution during hydroponic culture from the $4^{\text {th }}$ to the $8^{\text {th }}$ week and during rhizotron culture from the $8^{\text {th }}$ to the $14^{\text {th }}$ week.

Dry total biomasses are indicated in Figure 4 and Table 1. Shoot biomasses represented the largest fraction of total biomass. A. auriculoformis was specie producing the greatest amount of total biomass with $\sim 6 \mathrm{~g}$ per plant with the highest organ (shoot and roots) biomasses but no significant difference was observed with biomasses of $A$. mangium, with total biomass of $\sim 5 \mathrm{~g}$ per plant. A. crassicarpa displayed the lowest total biomass with $\sim 2 \mathrm{~g}$ per plant and lowest organ biomasses. The root/shoot ratios highlighted similar values with an average of $0.22 \pm 0.01$ at the end of experiment for all plants (Table 2).

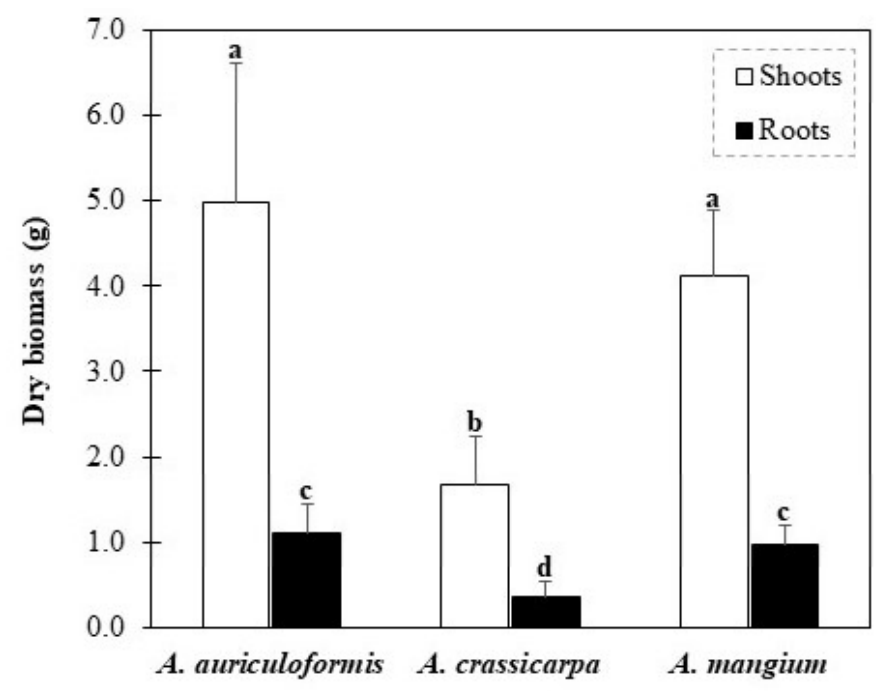

Figure 4: Dry biomass (shoots and roots) of plants. The letters correspond to different groups of significance obtained by ANOVA 1 factor and by the Tukey test $(\mathrm{p}=0.05)$ on three replicates of the various organs.

Table2. Bulk biomass, shoot and root biomasses and roots/shoot ratios of acacia species

\begin{tabular}{|l|l|l|l|}
\hline Parameters & A.auriculiformis & A. crassicarpa & A. mangium \\
\hline Total Biomass $(\mathrm{g})$ & $6.09 \pm 1.30$ & $2.04 \pm 0.46$ & $5.08 \pm 1.00$ \\
Shoots $(\mathrm{g})$ & $4.98 \pm 1.63$ & $1.68 \pm 0.57$ & $4.11 \pm 0.78$ \\
\hline Root $(\mathrm{g})$ & $1.12 \pm 0.33$ & $0.36 \pm 0.19$ & $0.96 \pm 0.25$ \\
Root/Shoot & $0.22 \pm 0.05$ & $0.21 \pm 0 ; 06$ & $0.23 \pm 0.03$ \\
\hline
\end{tabular}

\subsection{Characteristics of Rhizosphere Processes}

Rhizosphere processes characterized through the change in proton excretion, redox potential values and low molecular mass organic acids contents in rhizosphere soil of Acacia species are measured at the end of experiment (Figure 5; Figure 6). Results highlight that A. mangium and A. crassicarpa produced more protons in soil with respective averages of 4.50 and $3.84 \mu \mathrm{mol} \mathrm{H}^{+} . \mathrm{g}^{-1}$.day ${ }^{-1}$ than A. auriculiformis 
with an average of $2.40 \mu \mathrm{mol} \mathrm{H} \mathrm{H}^{+} \cdot \mathrm{g}^{-1}$.day ${ }^{-1}$. However according to the ANOVA test, no significant difference was observed in these proton released in soil between plant species (Figure 5A).

Redox potential indicate values in rhizosphere soil varying significantly according the ANOVA test from A. crassicarpa with an average value of $-96.34 \mathrm{mV}$ to A. auriculoformis with average value of $-63.30 \mathrm{mV}$ (Figure 5B). The redox potential value of $A$. mangium is intermediate between these two values, with an average of $-81.60 \mathrm{mV}$. Compared to control soil, A. crassicarpa and A. mangium reduced the soil while $A$. auriculoformis oxyded the grown medium
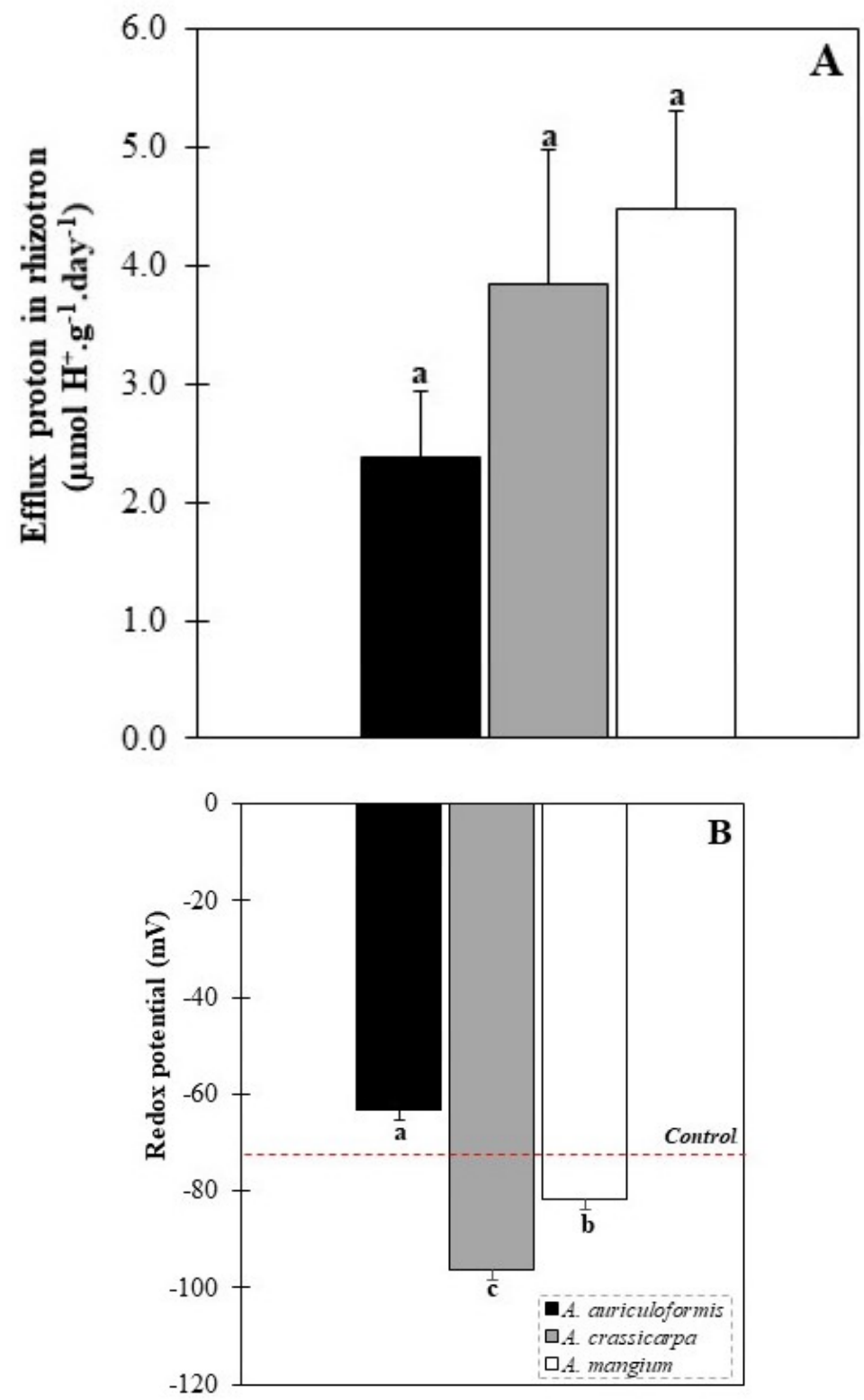

Figure 5: Efflux proton ( $\left.\mu \mathrm{mol} \mathrm{H} \mathrm{H}^{+} \cdot \mathrm{g}^{-1} \cdot \mathrm{day}^{-1}\right)(\mathrm{A})$ and potential redox $(\mathrm{mV})(\mathrm{B})$ measured in soils from rhizotron culture of acacia species. Red line represents the potential redox value of control soil. The letters correspond to different groups of significance obtained by ANOVA 1 factor and by the Tukey test $(p=0.05)$ on three replicates.

Figure 6 shows LMMOAs (oxalic, citric and malonic acids) detected and quantified in rhizosphere soil. Oxalic and acetic acids were the LMMOAS displaying the highest concentration in soil. Data indicate that the amounts of oxalic acid obtained under A. mangium were highest during the experiment, followed by A. auriculiformis and A. crassicarpa. For acetic acid, the highest amount was found under A. auriculiformis followed by A. mangium and A. crassicarpa, but no significant difference was observed between the three species. Similarly, no significant difference between these three species for malonic and citric acid contents. 


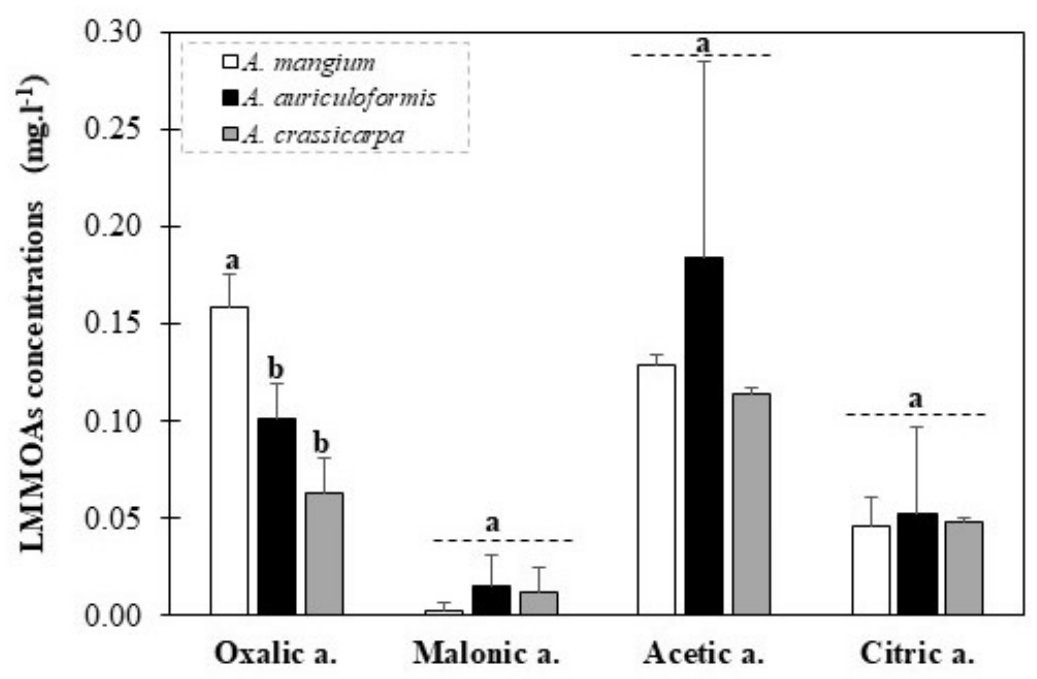

Figure 6: Low molecular mass organic acids (LMMOAs) measured in soils from rhizotron culture under acacia species. The letters correspond to different groups of significance obtained by ANOVA 1 factor and by the Tukey test $(p=0.05)$ on three replicates of LMMOAS for each plant.

\subsection{Heavy Metal Content of Soil and Plant Samples}

\subsubsection{Soils}

Total $\mathrm{Pb}$ and $\mathrm{Zn}$ soil content are indicated in Figure 7 showing that soils have a higher $\mathrm{Zn}$ contents ranging from 458.4 to $555 \mathrm{mg} \cdot \mathrm{kg}^{-1}$ compared to $\mathrm{Pb}$ contents ranging from 31 to $51.7 \mathrm{mg} \cdot \mathrm{kg}^{-1}$. For $\mathrm{Zn}$ concentration, no significant difference was observed between these three species according to the ANOVA test. In contrast, $\mathrm{Pb}$ content decreases on average by $\sim 21 \mathrm{mg} \cdot \mathrm{kg}^{-1}$ from control to planted soils among which no significant difference was observed.

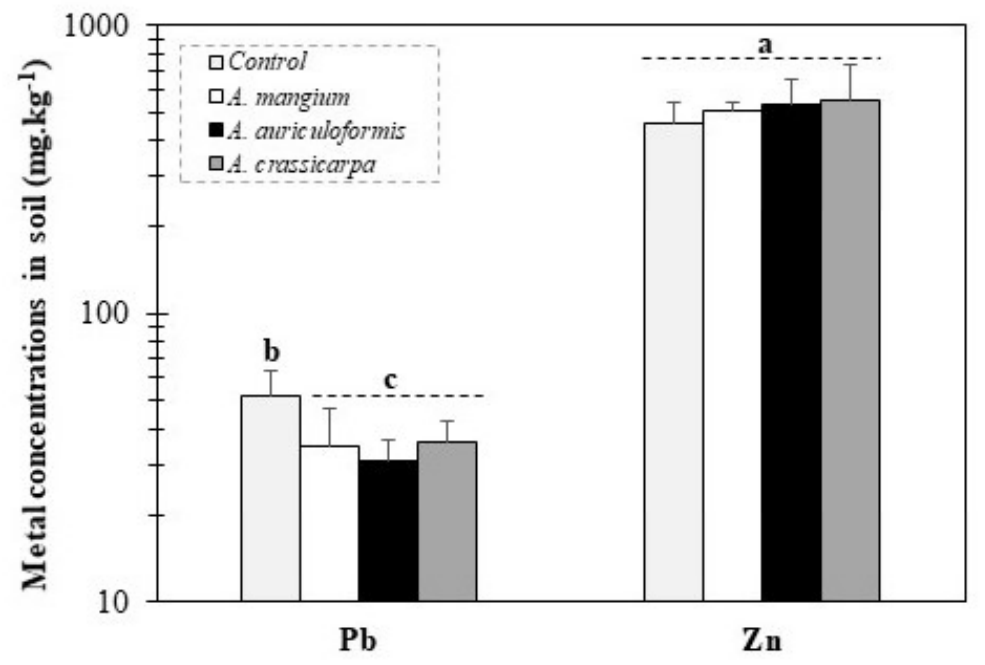

Figure 7: $\mathrm{Pb}$ and $\mathrm{Zn}$ concentrations (mg.kg ${ }^{-1}$ ) in soils from rhizotron culture. The letters correspond to different groups of significance obtained by ANOVA 1 factor and by the Tukey test $(p=0.05)$ on three replicates.

For the exchangeable metal fraction (Figure 8A), $\mathrm{Zn}$ had significant higher concentrations than $\mathrm{Pb}$ both for control soil and planted soils. No significant difference was observed according to the ANOVA test between control and $A$. auriculiformis in $\mathrm{Zn}$ content. These two treatments displayed higher exchangeable metal concentrations compared to A. crassicarpa and A. mangium treatments. For $\mathrm{Pb}$ concentration, no significant difference was observed whatever treatments.

For the acid-soluble metal fraction (Figure $8 \mathrm{~B}$ ), $\mathrm{Pb}$ had significant higher concentrations than $\mathrm{Zn}$ both for control and planted soils. However, for each metal, no statistically significant differences were observed whatever treatments. 

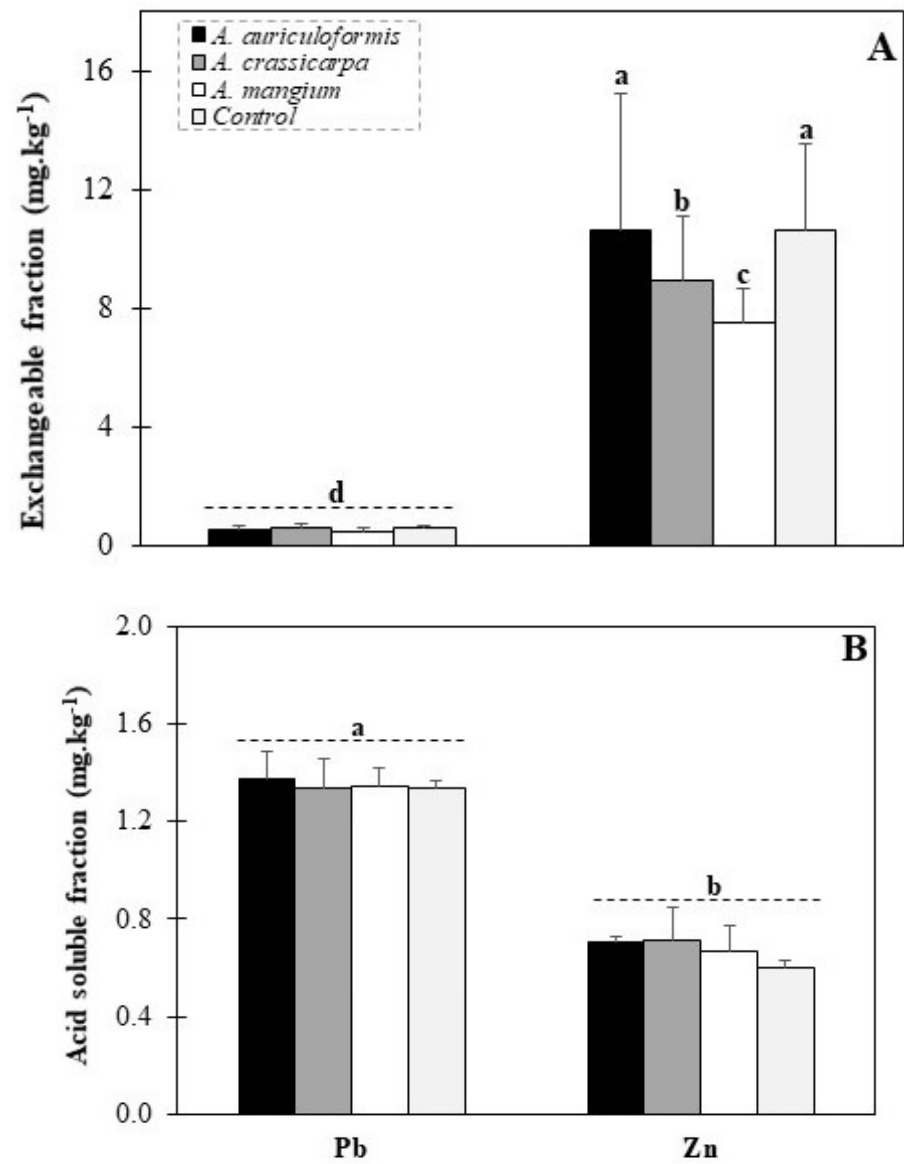

Figure 8: Exchangeable (A) and acid-soluble (B) fractions of $\mathrm{Pb}$ and $\mathrm{Zn}\left(\mathrm{mg}^{\mathrm{k}} \mathrm{kg}^{-1}\right)$ measured in soils from rhizotron culture. The letters correspond to the different groups of significance obtained by ANOVA 1 factor and by the Tukey test $(\mathrm{p}=0.05)$ on three replicates.

\subsubsection{Plants}

Zinc $(\mathrm{Zn})$ and lead $(\mathrm{Pb})$ concentrations measured in plant are shown in Figure 9. Data indicate that roots displayed, for all species, the highest metal contents except for $\mathrm{Zn}$ in A. auriculiformis. For $\mathrm{Zn}, A$. auriculiformis displayed higher content in shoot compared to A. mangium and A. crassicarpa. No significant difference was observed in shoot between $A$. mangium and A. crassicarpa. These two species displayed the highest $\mathrm{Zn}$ content in roots, significantly to $\mathrm{Zn}$ in root of A. auriculiformis (Figure 9A). Lead $(\mathrm{Pb})$ content showed significant difference in both shoot and roots between A. auriculiformis and others species (Figure 9B).

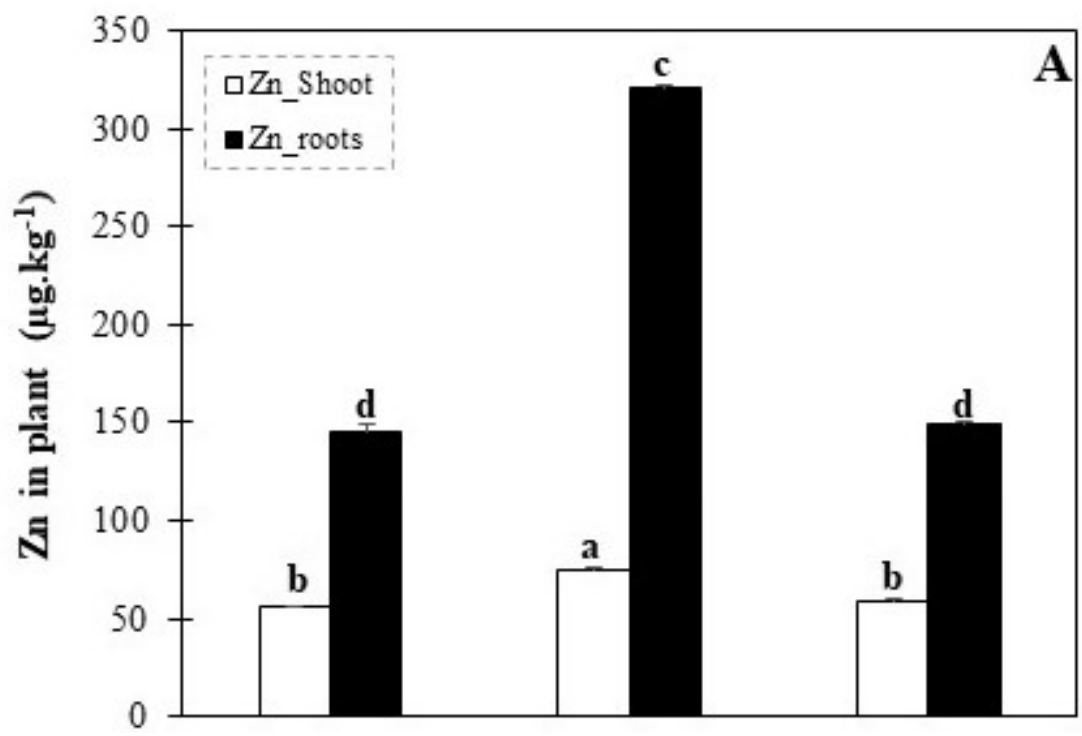




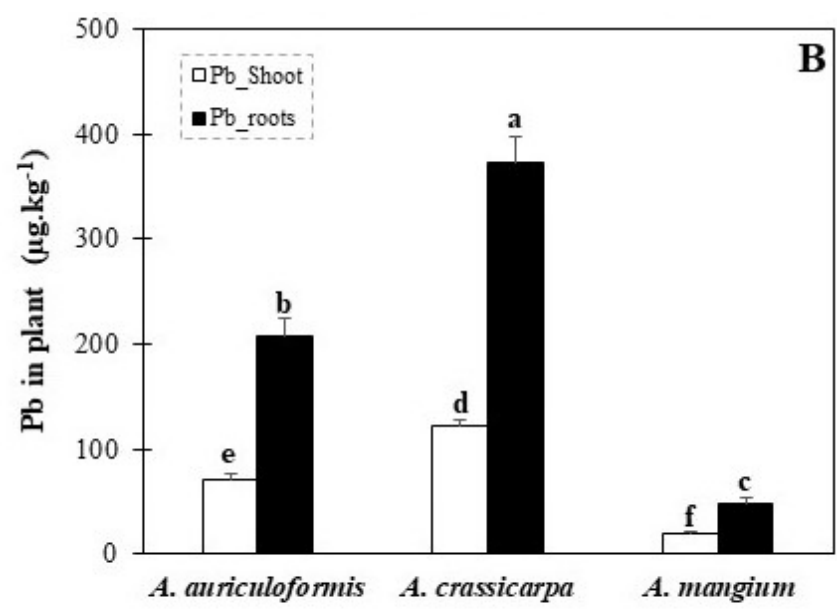

Figure 9: $\mathrm{Zinc}(\mathrm{A})$ and $\mathrm{Pb}(\mathrm{B})$ concentrations $\left(\mathrm{mg}^{\mathrm{kg}} \mathrm{k}^{-1}\right)$ in shoots and roots of acacia species. The letters correspond to different groups of significance obtained by ANOVA 1 factor and by the Tukey test $(\mathrm{p}=$ 0.05 ) on three replicates of each organ for acacia species.

Overall accumulated metals in plants indicated that A. crassicarpa stored the highest amount of $\mathrm{Zn}$ and $\mathrm{Pb}$ (Figure 10). For $\mathrm{Zn}$, the amount accumulated in the A. crassicarpa is $97 \%$ and $89 \%$ higher than $\mathrm{Zn}$ amount stored in A. auriculiformis and A. mangium respectively. For $\mathrm{Pb}$, the amount accumulated in $A$. crassicarpa is $78 \%$ higher than $\mathrm{Zn}$ amount stored in A. auriculiformis and 7 times higher than $\mathrm{Pb}$ stored in A. mangium (Figure 10). The amounts of $\mathrm{Zn}$ and $\mathrm{Pb}$ stored in plant biomasses represent $0.2 \%$ to $1.6 \%$ and $0.04 \%$ to $0.07 \%$ respectively of metal stocks in landfill-polluted soil used. Calculated translocation factors indicate $\mathrm{Zn}$ and $\mathrm{Pb}$ values are less than the unity (1) for A. auriculiformis, A. crassicarpa and A. Mangium suggesting metals are mainly accumulated in in roots.

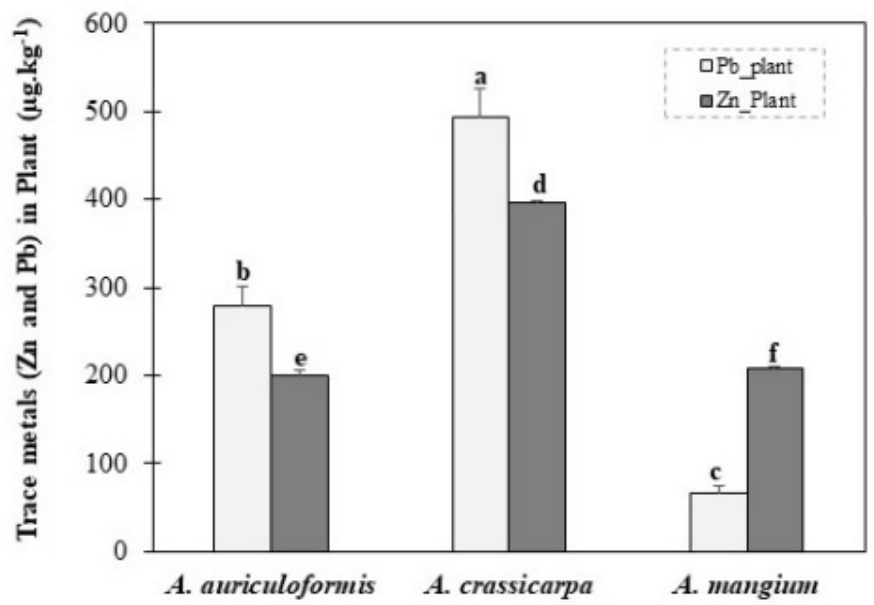

Figure 10: $\mathrm{Zinc}(\mathrm{A})$ and $\mathrm{Pb}(\mathrm{B})$ quantities $(\mathrm{mg})$ stored in acacia bulk biomass. The letters correspond to different groups of significance obtained by ANOVA 1 factor and by the Tukey test $(p=0.05)$ on three replicates of each organ for acacia species.

\section{DISCUSSION}

This study shows that there is a variability of biomass production between acacia species and in the rhizosphere adaptation processes as shown in Figure 11. The PCA of the three acacia species showed the separation of the species on the first axis ( $<<0.0001)$, which explained $52.35 \%$ of the variability (Figure 11). Furthermore, the A. mangium were separated along the PC1 axis ( $<<0.0001$ ), while $A$. crassicarpa and $A$. auriculiformis were not separated. This biomass production is the consequence of good growth of acacia indicated by shoot/root ratio. A. auriculiformis and A. mangium had the same tendencies in comparison to A. crassicarpa. Few studies using acacia as plant for in soil remediation show that the biomasses obtained at the end of culture are much higher than the biomasses obtained in this study (Majid et al. 2011, Majid et al. 2012, Ricardo et al. 2012, Mohd et al. 2013). This difference could be explained by the growing conditions of plants. Previous trials were done in open field for 8 to 13 months while our study was conducted in a greenhouse for 2 months. However, considering the rate 
of plant growth, the data indicate that plants in our study $\left(0.42\right.$ to $0.75 \mathrm{~cm}$. day $\left.{ }^{-1}\right)$ had growth rates and biomass production rates include in the range defined by those in the literature $\left(0.25\right.$ to $1.15 \mathrm{~cm}$.day $\left.{ }^{-1}\right)$ (Majid et al. 2012, Mohd et al. 2013). These acacia biomass productions reflect its ability to grow in polluted soil through implementation of mechanisms in order to take up or to sequestrate heavy metal in soil. These mechanisms take place in the rhizosphere, defined as zone at the root-soil interface (Seshadri et al. 2015). In this zone, roots react to both the physical and chemical changes in the soil environment. The response of roots not only affects the plants but also the soil, thereby bringing in chemical changes in the rhizosphere soil. Rhizosphere chemical change can be attributed to a combination of mechanisms including organic acids release in soil (Hinsinger et al. 2003), with amount varying according to the plant species (Kabata-Pendias and Pendias 1992). It has be demonstrated that among the carboxylates exuded in the rhizosphere, citrate and oxalate are expected to have the most dramatic effect due to their ability for complexation of heavy metals (Hinsinger 2001), especially for $\mathrm{Pb}$ and $\mathrm{Zn}$ (Weng et al. 2002) by forming organometallic complexes outside the roots (Mench et al. 1988). A. auriculiformis and A. mangium, the species with the largest biomasses and high total LMMOAs, displayed the lowest amount of metals stored in biomasses. In contrast, A. crassicarpa with lowest biomass and total LMMOAs displayed the highest heavy metal storage in biomass. This suggests that LMMOAs are not involved in metal up taken process but LMMOAs exudation allows the plant to tolerate high content of metal during it growth in polluted soil (Tangahu et al. 2011), and others rhizosphere processes may be involved in the heavy metals absorption. Acacia crassicarpa released more protons associated to lower redox potential value compared to other acacia species. The effect of $\mathrm{pH}$ and redox potential on the solubilization of heavy metals are well documented (e.g. Chuan et al. 1996). The $\mathrm{pH}$ and redox potential obtained in this study (between 7.09 and 7.15 for $\mathrm{pH}$, and between $-96.34 \mathrm{mV}$ and $-63.31 \mathrm{mV}$ for $\mathrm{Eh}$ ) are within this range of $\mathrm{pH}$ and Eh observed in well-drained soil, rich in organic matter. Results show a variability in proton excretion of acacia species. This proton excretion results in rhizosphere acidification (Hinsinger et al. 2003). Under these conditions, metals contained in the minerals, the organic material or other materials are then solubilized by total or partial hydrolysis releasing into the soil solution these metals in the ionic form (Singh et al. 2016, Broadley et al. 2007) and therefore potentially bioavailable for plants. However, there is no correlation between proton efflux and metal levels neither in plants, nor in soil. The amount of released protons in rhizosphere plot in the range of value found under other leguminous plants and play a key role in the solubilization of inorganic phosphorus (Alkama et al. 2009) and metals (Michaud et al. 2007, Bravin et al. 2009) in soils. Thus, the limited effect of releasing protons on metals solubilization in this study results from soil properties. Landfill soil used contain high organic matter and clay contents (Bongoua et al. 2018), inducing a strong soil buffering power able therefore to resist to $\mathrm{pH}$ change.

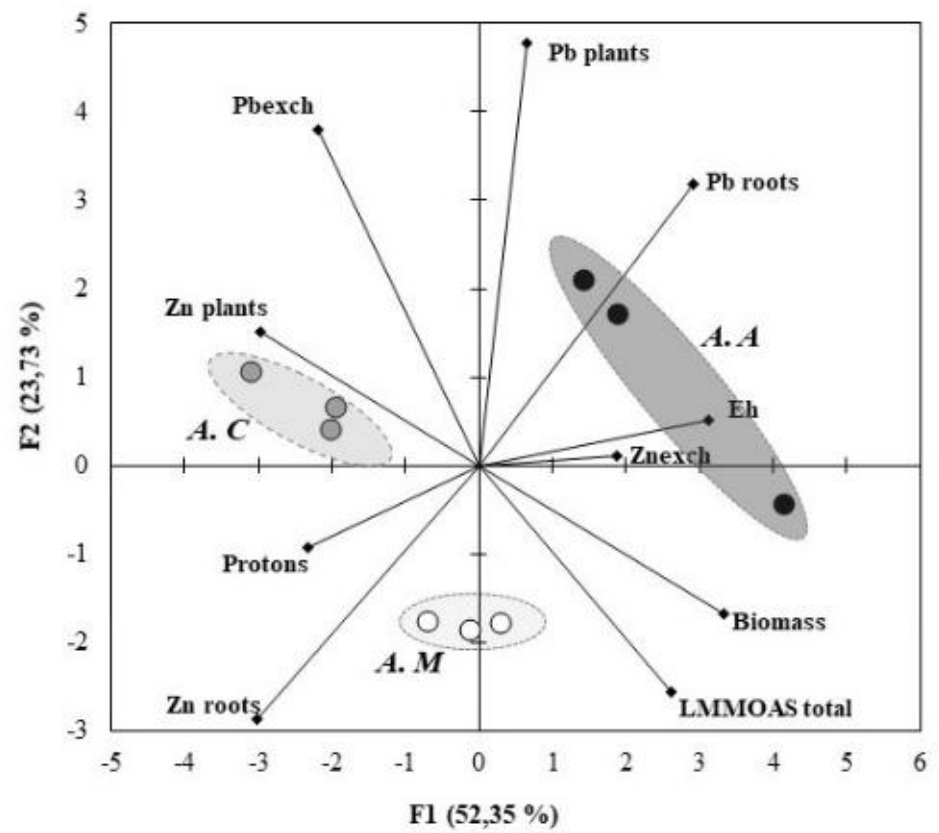

Figure 11: Principal component analysis of selected parameters analysed in this study. The ellipses cover $95 \%$ confidence limits for standard deviations of points that belong to a particular plant species 
Oxidation-reduction processes in the plant rhizosphere participate in mechanisms of adaptation and removal of metals by plants in polluted soils (Sebastian and Prasard 2014; Lissner et al. 2003). In our study, lower is the value of the redox potential in the rhizosphere, higher is the content of metals, especially for $\mathrm{Zn}$ in the plant. Morkunas et al. (2018) and Husson (2013) demonstrated that change in redox potential of the rhizosphere soil is a response of plants to high concentrations of metals in the medium. In fact, heavy metals cannot be degraded during bioremediation but can only be transformed from oxidation state to another. Due to a change in their oxidation state, heavy metals can be transformed to become either less toxic, more water-soluble (and thus can be removed through leaching), less water-soluble (which allows them to precipitate and become easily removed from the environment) or less bioavailable (Tangahu et al. 2011; Chestworth 2004). Acacia crassicarpa had the low value of the redox potential and accumulates the largest amount of metals ( $\mathrm{Zn}$ and $\mathrm{Pb}$ ), suggesting a speciation of these metals in its rhizosphere in bioavailable form. In soil solution and under alkaline soil conditions, zinc is mainly absorbed in the form of $\mathrm{ZnOH}^{+}$(Marschner 2011) or in the chelated form (Sekkon 2003, Weiss et al. 2005) and lead as $\mathrm{PbHCO}_{3}{ }^{-}$(Pourbaix aqueous Eh-pH diagram). The stabilization of $\mathrm{Zn}$ and $\mathrm{Pb}$ with organic acids (mainly citric acid) in addition to change in redox potential seems to be the strategies of acacia species for adaptation and growth in polluted soil.

\section{CONCLUSION}

In order to restore soil quality using a less expensive and more adapted to urban context, an experimental study has been undertaken on soil remediation techniques using tropical plants. The objective of this study was to determine rhizosphere processes controlling acacia tolerance and adaptation in polluted soil of former municipal landfill of the city of Bonoua, southeast of Côte d'Ivoire. The results study revealed that the factors governing heavy metal bioavailability in acacia rhizosphere were species, change in redox potential and organic acid production. The study of rhizosphere processes revealed a much larger proton excretion in the roots of A. crassicarpa and A. mangium than A. auriculiformis but the proton efflux did not affect the avaibility of metal due to soil characteristics with high buffer capacity. This proton excretion is associated with strong change in redox potential under A. crassicarpa and greater organic acid production with A. auriculiformis. Thus, A. crassicarpa extract from soil the greatest metal amount in soil while A. auriculiformis and A. mangium produced more biomasses. $A$. crassicarpa appears as the best plant for soil remediation due to its ability to both stored $\mathrm{Pb}$ and $\mathrm{Zn}$. Our experiments were carried out under controlled conditions for a short time ( 3 months), these results should be validated with additional work over a long period in field conditions. In addition, it would also be interesting to investigate the role of phytosiderophores in extracting metals from soils under Acacia species.

\section{ACKNOWLEDGMENT}

This study was financially supported by RESIPOL project. We are particularly grateful to Benoît Pollier of INRAe based at Nancy Center in France for analytical support of this work. The authors wish to extend their appreciation to Yvette Tshisungu for her constructive comments on this manuscript.

\section{REFERENCES}

[1] Alkama N., Bolou-Bi E.B., Vailhe H., Roger L., Ounane S.M. and Drevon J.J. 2009. Genotypic variability in $\mathrm{P}$ use efficiency for symbiotique nitrogen fixation is associer vite variation of proton efflux in cowpea rhizosphere. Soil Biology and Biochemistry, 41, pp.1814-1823.

[2] Bongoua-Devisme A., Bolou-Bi B.E., Kassin K., Balland-Bolou-Bi C., Gueable D., Adiaffi B., Yao-Kouame A. and Djagoua E. V. 2018. Assessment of heavy metal contamination degree of municipal open-air dumpsite on surrounding soils: Case of dumpsite of Bonoua, Ivory Coast. International journal of engineering research and general science. 6. 28-42

[3] Bravin M., Tentscher P., Rose J. and Hinsinger P. 2009. Rhizosphere pH gradient controls copper availability in a strongly acidic soil. Environmental Science and Technolology. 43:5686-5691.

[4] Broadley M. R., White P. J., Hammond J.P., Zelko L. and Lux A. 2007. Zinc in plants. New Phytologist, 17: 677-702.

[5] Chestworth W. 2004. Redox, soils, and carbon sequestration. Edafologia 11:37-43.

[6] Chuan M.C., Shu G.Y. and Liu J.C.1996. Solubility of heavy metals in a contamined soil: Effects of redox potentiel and pH. Water, Air, and Soil Pollution 90 : 543-556. 
[7] Edokpayi J., Durowoju O., Odiyo, J. 2018. Assessment of Heavy Metals in Landfill Leachate: A Case Study of Thohoyandou Landfill, Limpopo Province, South Africa. In Heavy Metal. doi: 10.5772/intechopen.74009.

[8] Ferri R., Hashim D., Smith D. R., Guazzetti S., Donna F., Ferretti E., Curatolo M., Moneta C., Beone G. M. and Lucchini R. G. 2015. Metal contamination of home garden soils and cultivated vegetables in the province of Brescia, Italy: Implications for human exposure. Science of the Total Environment, 518-519: 507-517.

[9] Fonge B.A, Nkoleka E.N, Asong F.Z, Ajonina S.A, Che V.B. 2007. Heavy metal contamination in soils from a municipal landfill, surrounded by banana plantation in the eastern flank of Mount Cameroon African. Journal of Biotechnology $16: 1391-1399$.

[10] Guety T.H., Kone B., Yao G.F., Kouakou N.Y. and Yao-Kouame A., (2015). Concentrations of Cadmium, Copper, Lead and Zinc in Soils and Vegetable Organs from Periurban Agriculture Areas of Abidjan in Cote d'Ivoire. Journal of Agriculture and Ecology Research International 3:12-23.

[11] Henrique N. C., Luiz E. D., Maurício D. C., Naiara V.C., Aristéa A. A., Roberto J. G., Izabela F. F. and Sandra P. M. A. 2013. Arsenic toxicity in Acacia mangium willd. And Mimosa caesalpiniaefolia benth. Seedling Sociedade Brasileira de Ciência do Solo 37:1423 1430.

[12] Hinsinger P. 2001. Bioavailability of trace elements as related to root-induced chemical changes in the rhizosphere. In: Gobran, G.R., Wenzel, W.W., Lombi, E. (Eds.), Trace Elements in the Rhizosphere. CRC Press LCC, Boca Raton, Florida, USA, pp. 25-41.

[13] Hinsinger P., Plassard C., Tang C.and Jaillard B. 2003. Origins of root-mediated pH changes in the rhizosphere and their responses to environnemental constraints: A review. Plant Soil 248 : 43-59.

[14] Husson O. 2013. Redox potential (Eh) and $\mathrm{pH}$ as drivers of soil/plant/microorganism systems: a transdisciplinary overview pointing to integrative opportunities for agronomy. Plant and Soil 362 : 389-417

[15] Kabata-Pendias A. and Pendias H.2001. Trace elements in soils and plants. CRC Press, Boca Raton Fl.

[16] Khattabi H. 2002. Intérêt de l'étude des paramètres hydrogéologiques et hydrobiologies pour la compréhension du fonctionnement de la station de traitement des lixiviats de la décharge d'ordure ménagères d'Etueffont (Belfort, France). Ph.D. Thesis, 171p.

[17] Kouamé I. K., Gone D. L., Savane I., Kouassi E. A., Koffi K., Goula B. A. and Diallo M. 2006. Relative mobility of heavy metals resulting from Akouédo landfill and assessment of Continental Terminal groundwater contamination risk (Abidjan-Côte d'Ivoire). Afrique Science $2: 39-56$.

[18] Lissner J., Mendelssohn I.A., Anastasiou C.A. 2003. Method for cultivating plants under contrôle redox intensities in hydroponics. Aquatic botany 76: 93-108.

[19] Majid N.M., Islam M.M., Justin V., Abdu A. and Ahmadpour P. 2011. Evaluation of heavy metal uptake and translocation by acacia mangium as a phytoremediator of copper contaminated soil. African Journal of Biotechnology 10: 8373-8379.

[20] Majid N. M., Islam M. M. and Lydia M. 2012. Heavy metal uptake and translocation by mangium (Acacia mangium) from sewage sludge contaminated soil. Autralian Journal of Crop Science 6: 1228-1235.

[21] Marschner H. 2011. Mineral Nutrition of Higher Plants, 3rd eds. London, UK, Academic Press, 672p.

[22] Mench M., Morel J.L., Guckert A.and Guillet B.1988. Metal binding with root exudates of low molecular weight. Journal of Science 39:521-27.

[23] Michaud A., Bravin M., Galleguillos M. and Hinsinger P. 2007. Copper uptake and phytotoxicity as assessed in situ for durum wheat (Triticum turgidum durum L.) cultivated in $\mathrm{Cu}$-contaminated, former vineyard soils. Plant and Soil 298. 99-111.

[24] Mohd S.N., Majid N.M., Shazili N.A.M. and Abdu A. 2013. Growth Performance, Biomass and Phytoextraction Efficiency of Acacia mangium and Melaleuca cajuputi in Remediating Heavy Metal Contaminated Soil. American Journal of Environmental Science 9: 310-316.

[25] Morkunas I., Wozniak A., Mai V. C., Rucinska-Sobkowiak R. and Jeandet P. 2018. The Role of heavy metals in plant response to biotic stress. Molecules 23: 2320.

[26] Mulchi C., Adamu C.A., Bell P.F.and Chaney R.L. 1992. Residual heavy metal concentrations in sludge amended coastal plain soils. II: Predicting metal concentrations in tabacco from soil test information. Communications in Soil Science and Plant Analysis 23:1053-1069.

[27] Nanven N. D., Egila and J. N. and Lohdip Y. N. 2015. Heavy Metal Concentrations in Some Vegetables Grown in a Farm Treated with Urban Solid Waste in Kuru Jantar, Nigeria. British Journal of Applied Science and Technology 8: 139-147

[28] Ricardo A.B., Orivaldo J.J., Rosa M.P., Rosângela S., Da Silva E.M., Sílvio R.T., Frederico H.L., Luiz F.M. and Antonia G.T. 2012. Selection of Leguminous Trees Associated with Symbiont Microorganisms for Phytoremediation of Petroleum Contaminated Soil. Water Air Soil Pollution 223:5659-5671. 
[29] Sebastian A. E.T. and Prasard M.V. 2014. Cadmium minimization in rice. A review. Agronomy for Sustainable Development 34, pp.155-173.

[30] Seshadri B., Bolan N.S. and Naidu R. 2015. Rhizosphere-induced heavy metal(loid) transformation in relation to bioavailability and remediation. Journal of Soil Science and Plant Nutrition, 15 : 524-548.

[31] Sekkon, B.S. 2003. Chelates for Micronutrient Nutrition among Crops. Resonance 8 (7), pp.46-53.

[32] Singh S., Parihar P., Singh R. and Singh V.P. 2016. Heavy metal tolerance in plants: role of transcriptomics, proteomics, metabolomics, and bionomics. Frontiers in plant science 6: 1143.

[33] Soro N., Ouattara L., Dongo K., Kouadio E. K., Ahoussi E. K., Soro G., Oga M.S., Savane I. and Biemi J., (2010). Déchets municipaux dans le District d'Abidjan en Côte d'Ivoire: sources potentielles de pollution des eaux souterraines. $12: 2203-2219$.

[34] Tangahu B. V., Abdoullah S.R., Basri H., Idris M., Anuar N. and Mukhlisin M. (2011). A Review on heavy metals ( $\mathrm{As}, \mathrm{Pb}$ and $\mathrm{Hg}$ ) uptake by plants through phytoremediation, International Journal of Chemical Engineering 2011: 1-31.

[35] Uddh-Söderberg T. E., Gunnarsson S. J., Hogmalm K. J., Lindegård M.I.B.G. and Augustsson

[36] Vittori-Antisari L., Orsini F., Marchetti L., Vianello G. and Gianquinto G. 2015. Heavy metal accumulation in vegetables grown in urban gardens. Agronomy for Sustainable Development. 35 : 113-1147.

[37] Vongdala N., Tran H.D., Dang X. T. \& Teschke R. and Khanh T. 2018. Heavy Metal Accumulation in water, soil, and plants of municipal Solid waste landfill in Vientiane, Laos. International Journal of Environmental Research and Public Health 16-22 : 1-13.

[38] Weiss D.J., Mason T.F.D., Zhao F.J., Kirk G.J.D., Coles B.J and Horstwood M.S. A. 2005. Isotopic discrimination of zinc in higher plants. New Phytologist 165 : 703-710.

[39] Weng L.P., Temminghoff E.J.M., Lofts S., Tipping E. and Van Riemsdijk W.H. 2002 Complexation with dissolved organic matter and solubility control of heavy metals in a sandy soil. Environmental Science and Technology 36:4804- 4810.

Citation: BOLOU-BI B. Emile, et.al., "Contribution of Rhizosphere Processes to Acacia Seedlings Adaptation into Polluted Soils of a Municipal Landfill (Côte d'Ivoire) ", International Journal of Research in Environmental Science (IJRES), vol. 6, no. 3, pp. 36-48, 2020. Available: DOI: http://dx.doi.org/10.20431 /2454-9444.0603004

Copyright: (C) 2020 Authors. This is an open-access article distributed under the terms of the Creative Commons Attribution License, which permits unrestricted use, distribution, and reproduction in any medium, provided the original author and source are credited. 